\title{
Cytogenetic and Array-CGH Characterization of a Complex de novo Rearrangement Involving Duplication and Deletion of $9 p$ and Clinical Findings in a 4-Month-Old Female
}

\author{
P.J. Hulick ${ }^{a}$ K.M. Noonan ${ }^{a, c} \quad$ S. Kulkarni ${ }^{b} \quad$ D.J. Donovan ${ }^{b} \quad$ M. Listewnik ${ }^{b}$ \\ C. Ihm $^{\text {b }}$ J.M. Stoler ${ }^{\text {a, d, e }}$ S. Weremowicz ${ }^{\text {b, e }}$ \\ ${ }^{a}$ Harvard Partners Center for Genetics and Genomics, Medical Genetics Program and MGH Clinic, \\ ${ }^{b}$ Department of Pathology, Brigham and Women's Hospital, 'Pediatric Surgical Research Laboratories, \\ Massachusetts General Hospital, dDivision of Genetics, Children's Hospital, and ' Harvard Medical School, \\ Boston, Mass., USA
}

\section{Key Words}

aCGH $\cdot$ Cleft palate $\cdot$ Deletion 9p - Duplication 9p · FISH • Inversion $9 p$

\begin{abstract}
Approximately 15 patients with partial trisomy $9 p$ involving de novo duplications have been previously described. Here, we present clinical, cytogenetic, FISH and aCGH findings in a patient with a de novo complex rearrangement in the short arm of chromosome 9 involving an inverted duplication at 9 p24 $\rightarrow$ p21.3 and a deletion at 9pter $\rightarrow$ p24.2. FISH probes generated from BACs selected from the UCSC genome browser were utilized to verify this rearrangement. It is likely that some previously described duplications of $9 p$ may also be products of complex chromosomal aberrations. This report in which FISH and aCGH were used to more comprehensively characterize the genomic rearrangement in a patient with clinical manifestations of $9 p$ duplication syndrome underscores the importance of further characterizing cytogenetically detected rearrangements.
\end{abstract}

Copyright $\odot 2009$ S. Karger AG, Basel

\section{KARGER}

Fax +4161306 1234

E-Mail karger@karger.ch

www.karger.com
(C) 2009 S. Karger AG, Basel

$1424-8581 / 09 / 1263-0305 \$ 26.00 / 0$

Accessible online at:

www.karger.com/cgr
Duplication of short-arm material from chromosome 9 (or partial trisomy 9p) was first described by Rethore et al. [1970] and is now a well-described syndrome that has been documented in more than 150 patients [Rethore et al., 1970; Centerwall and Beatty-DeSana, 1975]. In most of these patients, the duplication $9 p$ is a result of an abnormal chromosome segregation of a balanced translocation in one of the parents [Baccichetti and Tenconi, 1973; Wajntal et al., 1985]. De novo duplications of this chromosomal region have been previously described in approximately 15 patients [Chiyo et al., 1976; Baccichetti et al., 1979; Fryns et al., 1979; Motegi et al., 1985; Mattina et al., 1987; Haddad et al., 1996; Fujimoto et al., 1998; Tsezou et al., 2000; Krepischi-Santos and Vianna-Morgante, 2003]. Patients with partial trisomy of the short arm of chromosome 9 often display a wide spectrum of clinical symptoms including developmental delay, craniofacial abnormalities (bulbous nose, hypertelorism, downward-slanting palpebral fissures), limb abnormalities (short fingers and toes with small nails, fifth-finger clinodactyly) and skeletal malformations. 
Fig. 1. Patient at 4 months of age. A Front view: note the large-appearing eyes, hypertelorism, bulbous nose, thin vermilion, small-appearing mouth and subtle micrognathia. B Clinodactyly of the 5th digit.
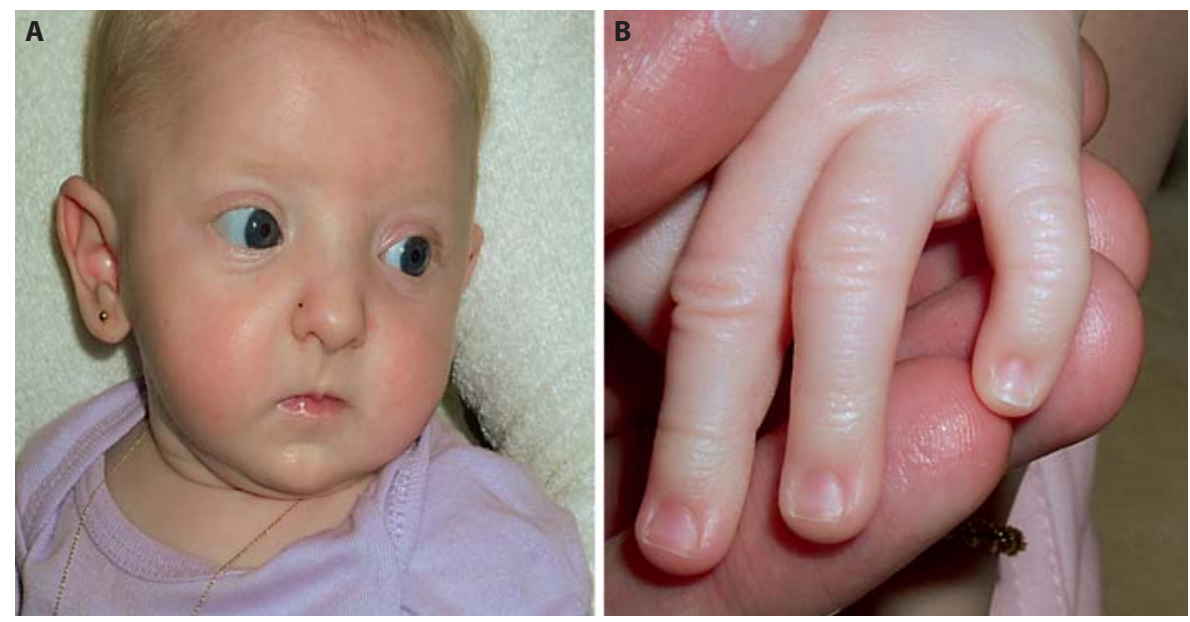

Here, we describe a patient with a de novo complex rearrangement of the short arm of chromosome 9, involving duplication and deletion of chromosomal material detected by GTG banding, characterized and delineated further by FISH and array CGH.

\section{Clinical Report}

A 4-month-old female infant was evaluated in the craniofacial clinic for a complete cleft of the soft palate. She had difficulty in feeding with aspirations and related poor weight gain. She was born to a 25 -year-old gravida III para II mother of mixed European descent and 21year-old father of English descent. Her mother presented late for prenatal care due to insurance issues. There were no reported exposures to medications, alcohol or tobacco. Prenatal ultrasound monitoring at an outside institution during the third trimester was notable for decreased growth, however, prenatal chromosome analysis was not performed. Vaginal delivery was induced 9 days prior to the due date without complications. Apgar scores were 9 and 10 after 1 and $5 \mathrm{~min}$. Birth weight was $2.414 \mathrm{~kg}$ (3rd percentile for gestational age), head circumference was 33 $\mathrm{cm}$ (25th percentile for gestational age), and length was $45.7 \mathrm{~cm}(<3 \mathrm{rd}$ percentile for gestational age). Family history was unremarkable for cleft lip/palate or other birth defects, known chromosomal abnormalities and recurrent miscarriages. There was no known consanguinity. On examination, the patient was alert and active with a normal body habitus. Length, weight, and head circumference at 4 months were $55.5 \mathrm{~cm}$ (2nd percentile), $4.83 \mathrm{~kg}$ (3rd percentile), and $39.4 \mathrm{~cm}$ (21st percentile), respective- ly. Notable findings included the appearance of large, prominent deep set eyes with an interpupillary distance of $4.5 \mathrm{~cm}$ (50th-75th percentile) and an intercanthal distance of $2.6 \mathrm{~cm}$ (75th-97th percentile). Formal ophthalmology evaluation did not reveal macrocornea or other significant structural abnormalities. Additional findings included complete cleft of the soft palate, cupped but not low-set ears, bulbous nose, thin upper lip, small mouth and mild micrognathia. The remaining physical examination was notable for normal palmar creases, significant fifth-digit clinodactyly bilaterally, with only one 5th digital crease, dimpling of the elbows, and sacral dimples bilaterally. No murmurs were appreciated on the cardiac exam and the rest of the physical examination was unremarkable (fig. 1A and B). At the initial encounter (age of 4 months), appropriate developmental milestones had been achieved.

The combination of the intrauterine growth retardation, dysmorphic facial features and cleft of the soft palate raised the possibility of a syndrome diagnosis. Blood was sent for chromosome analysis.

The patient was seen at follow-up at 15 months of age. Interim history was notable for surgical repair of her cleft approximately 3 months prior to examination. At 15 months, her development was delayed, as she was not able to sit unsupported for long periods of time. She was crawling but could not pull to a stand or cruise, and had limited vocalization.

Further evaluation revealed a normal echocardiogram at 22 months, normal ophthalmology examination and moderate right-sided renal pelviectasis. New family history revealed a maternal second cousin with a cleft lip, but further details were not available. Length, weight, and 
head circumference were $73.5 \mathrm{~cm}$ (8th percentile), $9.4 \mathrm{~kg}$ (8th percentile), and $45.1 \mathrm{~cm}$ (12th percentile). In addition to the previously described features, her ears had developed a more cupped and floppy appearance, her big toes appeared broadened with dystrophic nails bilaterally, and there was mild hypotonia.

\section{Materials and Methods}

Karyotyping and Fluorescence in situ Hybridization

Metaphase spread preparations from the patient and her parents' peripheral blood lymphocyte cultures and GTG-banding were performed according to standard methods. FISH was initially performed on the patient's metaphase chromosomes using a whole chromosome 9 painting probe (Rainbow Scientific Inc., Windsor, Conn., USA) according to the manufacturer's protocol. Additional FISH experiments were performed using BAC clones RP11-399M15 and RP11-32D4 (BACPAC Resources, Children's Hospital Oakland Research Institute, Oakland, Calif., USA) and the TelVysion 9p probe (Abbott Molecular/Vysis, Inc., Downers Grove, Ill., USA). BAC DNA was isolated by standard procedures and direct-labeled with Spectrum Green and Spectrum Orange by nick translation (Abbott Molecular/Vysis, Inc.). Chromosomes were counterstained with 4',6-diamidino-2-phenylindole (DAPI) and images were captured using the CytoVysion Imaging System (Applied Imaging, Pittsburg, Pa., USA).

\section{Array Comparative Genomic Hybridization}

A human genome CGH Microarray 244K (Agilent Technologies, Inc., Santa Clara, Calif., USA) was used to define more precisely the duplicated and deleted chromosomal regions [Iafrate et al., 2004]. This array platform contains 236,000 60-mer oligonucleotide probes spanning coding and noncoding genomic sequences with a median spacing of $7.4 \mathrm{~kb}$ and $16.5 \mathrm{~kb}$, respectively. More than $99 \%$ of the genes on this array contain 3 or more probes and therefore a minimum of 3 consecutive probes was used as a cutoff for calling a genomic imbalance. The CGH analytics software was used for aberration analysis and visualization, using the Aberration Detection Method algorithm, ADM2, to make the genomic imbalance calls. Probe sequence annotation was based on NCBI Build 36.1 (hg18) of the human genome. 'Benign' copy number variants were identified via the Database of Genomic Variants (http://projects.tcag.ca/variation/) based on information deposited as of November 20, 2008.

\section{Results}

\section{Karyotype and Fluorescence in situ Hybridization}

Based on GTG-banding analysis, an inverted duplication was detected between bands p21 and p23 on chromosome 9, and since parental karyotypes were both normal, the patient's karyotype was designated as 46,XX,dup(9)(p23p21)dn (fig. 2A). FISH analysis using a whole chromosome 9 painting probe confirmed that the

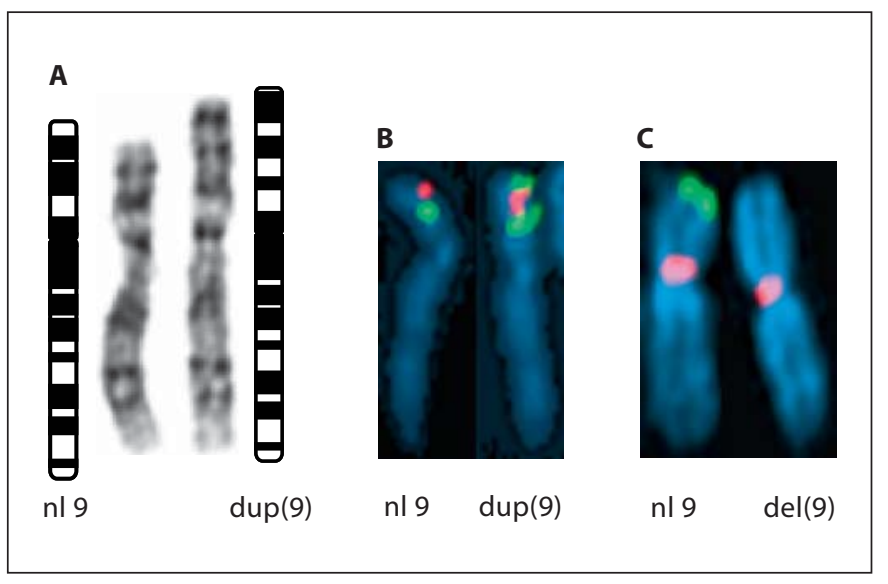

Fig. 2. Partial karyotype of the patient showing the normal (left) and the abnormal (right) chromosome 9. A GTG banding. B FISH with the RP11-399M15 probe (spectrum green) and the RP1132D4 probe (spectrum orange). Note the duplication and reverse orientation of the hybridization signals on the abnormal chromosome 9. C FISH with the Tel9p probe (spectrum green) and the CEP9 probe (spectrum orange) demonstrating deletion on the abnormal chromosome 9.

extrachromosomal material was of chromosome 9 origin. The suspected inversion of the duplicated segment and the deletion revealed by aCGH were confirmed by FISH using RP11-399M15 and RP11-32D4 BAC clones and a TelVysion $9 \mathrm{p}$ probe as shown in fig. $2 \mathrm{~B}$ and C. FISH performed on parental chromosomes revealed a normal hybridization pattern with no evidence of cryptic inversion.

\section{Array Comparative Genomic Hybridization}

Oligonucleotide-based array $\mathrm{CGH}$ confirmed and precisely delineated the observed duplication and additionally revealed a deletion on the short arm of chromosome 9 (fig. 3). The deleted region begins at the 9ptermost informative probe on the array (at nucleotide position 194,193; 9p24.3) and extends proximally to nucleotide $3,745,031$ (9p24.2). The duplicated region begins at nucleotide $3,761,025$ (9p24.2) and continues proximally to nucleotide 20,111,633 (9p21.3). This corresponds to a deletion of at least $3.55 \mathrm{Mb}$ in size and a duplication of at least $16.35 \mathrm{Mb}$ in size. No known genes were identified at the breakpoints and no significant duplications (i.e., $>1000 \mathrm{bp}$ ) were observed within $1 \mathrm{Mb}$ upstream and downstream of the duplication breakpoints. A list of genes mapped to the duplicated and deleted regions is included in online supplementary table 1 (www.karger.com/doi/10.1159/000251966). 


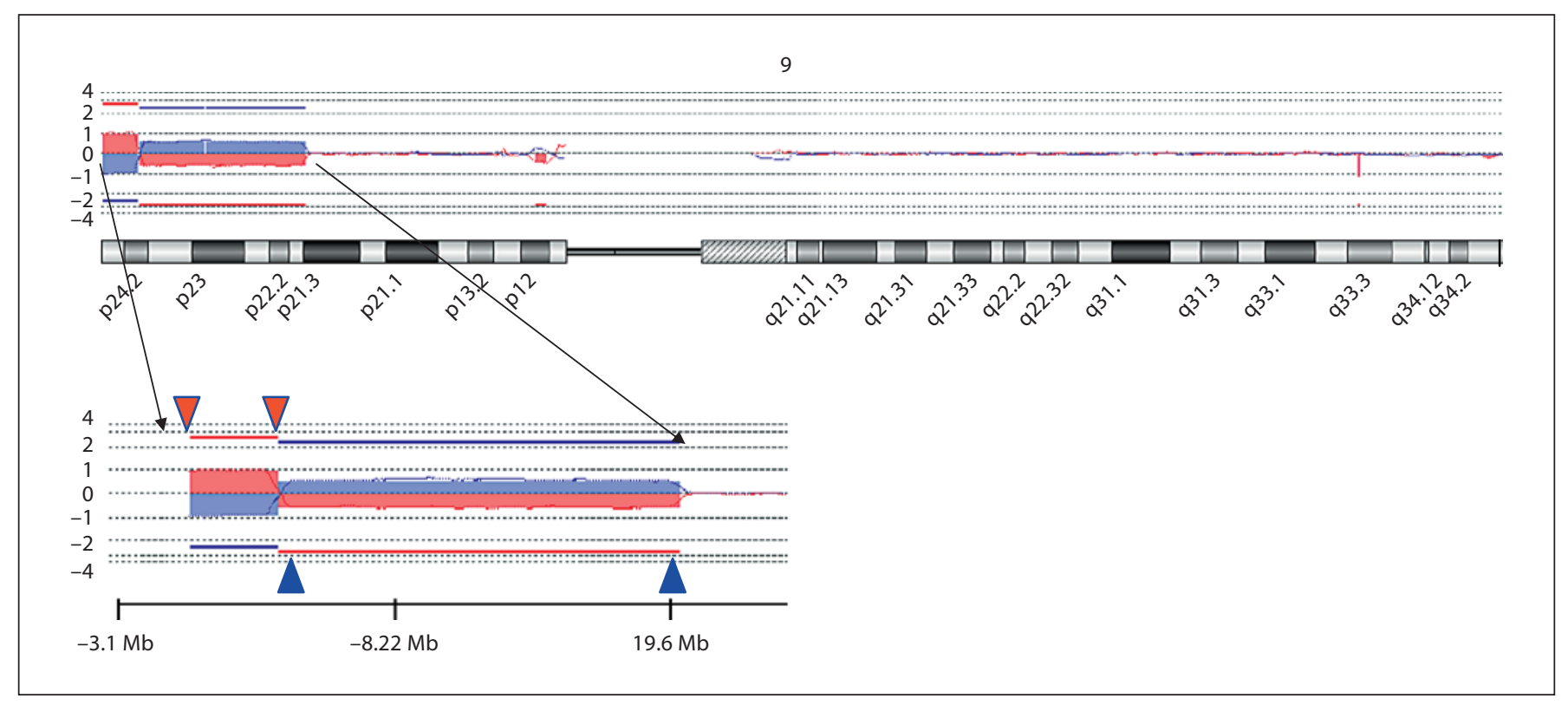

Fig. 3. Oligonucleotide aCGH results of chromosome 9 in a patient with 9 p duplication and deletion. The deletion is shown with red arrows on the upper side and duplication is shown with blue arrows on the lower side.

\section{Discussion}

Duplication of $9 \mathrm{p}$ is well described in the scientific literature with more than 150 patients reported. However, most of these reported duplications are due to malsegregation of chromosomes inherited from a parent with a reciprocal translocation involving chromosome 9 , with relatively few pure $9 \mathrm{p}$ duplications arising de novo [Chiyo et al., 1976; Baccichetti et al., 1979; Fryns et al., 1979; Motegi et al., 1985; Mattina et al., 1987; Haddad et al., 1996; Fujimoto et al., 1998; Tsezou et al., 2000; Bonaglia et al., 2002; Krepischi-Santos and Vianna-Morgante, 2003; Swinkels et al., 2008]. Despite varying sizes of duplicated chromosomal segments, there is a significant overlap in clinical features in duplication $9 \mathrm{p}$ syndrome, which is attributed to the terminal segment of $9 \mathrm{p}$. The characteristic facial features include microcephaly, enophthalmos, hypertelorism, antimongoloid slant of palpebral fissures, micrognathia, broad nasal root with bulbous nasal tip, downturned corners of the mouth, and anomalous ears [Haddad et al., 1996; Fujimoto et al., 1998]. Other distinctive trisomy 9p manifestations reported are psychomotor retardation, growth retardation, hypotonia, strabismus, myopia, short neck, brachymesophalangy, and small hands and feet. We reviewed the findings of patients with de novo 9p duplication (no other cytogenetic abnormali- ties), and compared the findings with our patient (table 1). The phenotype of our patient is similar to the malformation spectrum frequently described in other patients with partial trisomy $9 \mathrm{p}$ (fig. 1A and B). However, some features noted in our patient differed from previously described patients with duplication $9 \mathrm{p}$, such as the cleft palate and large eyes. Therefore to better characterize the chromosome 9 abnormality, conventional cytogenetics was supplemented with FISH on metaphase chromosomes and oligonucleotide-based aCGH.

The aCGH-based analysis defined more precisely the location and size of the duplication and revealed an unexpected 3.55-Mb terminal 9p deletion. Patients with deletion $9 p$ have been characterized both clinically and $c y-$ togenetically. Alfi et al. [1976] described the first series of patients and others have further characterized the distinctive features of trigonocephaly, midface hypoplasia, upward-slanting palpebral fissures, and a long philtrum. Our patient did not have all of these characteristic features (table 2), and this could be due to the fact that her deletion does not include what is thought to be the critical region at 9 p22 responsible for the classical 9p deletion phenotype [Alfi et al., 1973, 1976; Huret et al., 1988; Christ et al., 1999; Kawara et al., 2006; Swinkels et al., 2008].

A complex de novo rearrangement of $9 p$ involving duplication and deletion has been characterized by GTG 
Table 1. Clinical features and chromosome breakpoints in patients with de novo pure 9p duplication.

\begin{tabular}{|c|c|c|}
\hline Authors & Duplication & Congenital anomalies \\
\hline Our patient & $\begin{array}{l}\mathrm{p} 21.3-\mathrm{p} 24.2 \\
\text { Inverted }\end{array}$ & $\begin{array}{l}\text { Cleft palate, absent uvula, difficulty with feeding, poor weight gain, clinodactyly, dystrophic nails, } \\
\text { growth retardation, developmental delay, large palpebral fissures, hypertelorism, bulbous nose, cup- } \\
\text { shaped ears, mild micrognathia and hypotonia }\end{array}$ \\
\hline $\begin{array}{l}\text { Baccichetti et al. } \\
\text { (1979) }\end{array}$ & $\begin{array}{l}\text { p21-p24 } \\
\text { Inverted }\end{array}$ & $\begin{array}{l}\text { Mild mental retardation, short stature, lip anomalies, microcephaly, hypertelorism, malformed } \\
\text { ears, antimongoloid slant, bulbous nose, clinodactyly, single palmar crease }\end{array}$ \\
\hline $\begin{array}{l}\text { Bussani et al. } \\
\text { (1991) }\end{array}$ & p12-p22 & $\begin{array}{l}\text { Developmental delay, down-slanting palpebral fissures, bulbous nose, downturned corners of the } \\
\text { mouth, cup-shaped ears, short neck, transverse palmar crease, 5th-digit clinodactyly }\end{array}$ \\
\hline $\begin{array}{l}\text { Chiyo et al. } \\
(1976)\end{array}$ & $\begin{array}{l}\mathrm{p} 21-\mathrm{p} 24 \\
\text { Inverted }\end{array}$ & $\begin{array}{l}\text { Severe mental retardation, microcephaly, hypertelorism, malformed ears, antimongoloid slant, bul- } \\
\text { bous nose, clinodactyly, single palmar crease, nail hypoplasia }\end{array}$ \\
\hline $\begin{array}{l}\text { Fujimoto et al. } \\
\text { (1998) }\end{array}$ & $\begin{array}{l}\mathrm{p} 22-\mathrm{p} 24 \\
\text { Tandem }\end{array}$ & $\begin{array}{l}\text { Mental retardation, short stature, lip anomalies, malformed ears, antimongoloid slant, bulbous } \\
\text { nose }\end{array}$ \\
\hline $\begin{array}{l}\text { Guanciali et al. } \\
(2000)\end{array}$ & $\mathrm{p} 22-\mathrm{p} 24$ & $\begin{array}{l}\text { Microcephaly, hypotonia, deep-set eyes with hypertelorism, down-slanting palpebral fissures, } \\
\text { wide/short neck, low-set and malformed ears, wide/prominent nose with wide philtrum, single pal- } \\
\text { mar crease }\end{array}$ \\
\hline $\begin{array}{l}\text { Haddad et al. } \\
(1996)\end{array}$ & $\begin{array}{l}\mathrm{p} 22-\mathrm{p} 22 \\
\text { Tandem }\end{array}$ & $\begin{array}{l}\text { Mild mental retardation, short stature, lip anomalies, microcephaly, malformed ears, antimongol- } \\
\text { oid slant, bulbous nose, clinodactyly }\end{array}$ \\
\hline $\begin{array}{l}\text { Krepischi- } \\
\text { Santos et al. } \\
(2003)\end{array}$ & $\begin{array}{l}\text { Multiple } \\
\text { patients }\end{array}$ & $\begin{array}{l}\text { Developmental delay, microcephaly, frontal bossing, low-set frontal hairline, facial hirsutism, hy- } \\
\text { pertelorism, deep-set and downslanting eyes, epicanthus, bulbous nose, short philtrum, down- } \\
\text { turned corners of the mouth, small teeth, retrognathia, large/protruding ears with overfolded heli- } \\
\text { ces, hypoplastic middle phalanges, hypoplastic nails, clinodactyly, single interphalangeal flexion } \\
\text { crease of the fifth finger, bilateral single transverse creases, absent palmar triradii c, cryptorchidism, } \\
\text { scoliosis }\end{array}$ \\
\hline $\begin{array}{l}\text { Sanlaville et al. } \\
\text { (1999) }\end{array}$ & $\begin{array}{l}\text { p21-pter } \\
\text { Tandem }\end{array}$ & $\begin{array}{l}\text { Mild mental retardation, enophthalmos, antimongoloid slant, lip anomalies, bulbous nose, clino- } \\
\text { dactyly, single palmar crease }\end{array}$ \\
\hline $\begin{array}{l}\text { Temtamy et al. } \\
(2007)\end{array}$ & p21-p24 & $\begin{array}{l}\text { Patients } 2 \text { and } 3 \text { - developmental delay, brachycephaly, hypertelorism, downslanting eyes, bulbous } \\
\text { nose, short/deep philtrum, downturned corners of the mouth, macrostomia, low-set ears, short } \\
\text { neck, aplasia/hypoplasia of terminal phalanges, clinodactyly, broad hallux, nail hypoplasia }\end{array}$ \\
\hline $\begin{array}{l}\text { Tsezou et al. } \\
(2000)\end{array}$ & $\begin{array}{l}\mathrm{p} 12-\mathrm{p} 24 \\
\text { Tandem } \\
\text { Inverted }\end{array}$ & $\begin{array}{l}\text { Patient } 1 \text { - brachycephaly, high forehead, hypertelorism, epicanthus, deep-set eyes, bulbous nose, } \\
\text { thin upper lip, downturned corners of the mouth, cup-shaped ears, micro-/retrognathia, short } \\
\text { broad neck, widely spaced nipples, single palmar crease, syndactyly of the 3rd-4th fingers and } 2 \text { nd- } \\
\text { 4th toes' hypoplastic nails, developmental delay } \\
\text { Patient } 2 \text { - developmental delay, brachycephaly, frontal bossing, hypertelorism, epicanthus, deep- } \\
\text { set eyes, strabismus, bulbous nose, short upper lip, downturned corners of the mouth, cup-shaped } \\
\text { ears, short broad neck, widely spaced nipples, short thumbs, single palmar creases }\end{array}$ \\
\hline
\end{tabular}

Bolding represents features in common with our patient. 
Table 2. Clinical features and chromosome breakpoints in patients with $9 \mathrm{p}$ deletion

\begin{tabular}{lll}
\hline Authors & Deletion & Congenital anomalies \\
\hline Our patient & p24.2-pter & $\begin{array}{l}\text { Cleft palate, absent uvula, difficulty with feeding, poor weight gain, clinodactyly, dystrophic nails, } \\
\text { growth retardation, developmental delay, large palpebral fissures, hypertelorism, bulbous nose, cup- } \\
\text { shaped ears, mild micrognathia and hypotonia }\end{array}$ \\
\hline $\begin{array}{l}\text { Livadas et al. } \\
(2003)\end{array}$ & p22 & Developmental delay, hypertelorism, depressed nasal bridge, low-set/dysmorphic ears, sex reversal \\
$\begin{array}{l}\text { Ogata et al. } \\
(1997)\end{array}$ & p23-pter & $\begin{array}{l}\text { Prominent forehead, anteverted nostrils, low-set ears, high/arched palate, micrognathia, puffy hands } \\
\text { and feet, funnel chest, microphallus, hypospadias, hypoplastic scrotum, ambiguous genitalia }\end{array}$ \\
$\begin{array}{l}\text { Swinkels et al. } \\
(2008)\end{array}$ & $\begin{array}{l}\text { Multiple } \\
\text { patients }\end{array}$ & $\begin{array}{l}\text { Major features: mental retardation, trigonocephaly, midface hypoplasia, long philtrum } \\
\text { Other features: developmental delay, hypertelorism, epicanthal folds, small palpebral fissures, flat } \\
\text { nasal bridge, anteverted nares, posteriorly rotated and low-set ears, micrognathia, microstomia, short, } \\
\text { neck, widely spaced nipples, hypotonia, nail abnormalities }\end{array}$ \\
\hline
\end{tabular}

Bolding represents features in common with our patient.

banding and FISH in 1 patient [Teebi et al., 1993]. A similar rearrangement has been recently investigated by routine cytogenetics and FISH as well as aCGH in 2 other patients [Swinkels et al., 2008]. These 3 patients and our case shown in table 3 clearly illustrate that rearrangements in this area of 9p may be more complex than originally assessed by routine cytogenetics. The phenotype of these 2 patients for whom the breakpoints and size of the dup/del have been precisely defined by aCGH differs from that of our patient and was more similar to the $9 p$ deletion phenotype [Swinkels et al., 2008]. This is most likely because they carry larger deletions involving 9p22 and duplications with more proximal breakpoints (at p12 and p13.3). The region of overlap between the former 2 patients and our patient appears to be limited to 9 p22.3 $\rightarrow$ p21.3. Since the structural configuration of the abnormal chromosome could not be determined from the aCGH results, FISH on metaphase chromosomes with selected BAC clones was utilized to establish the orientation of the rearranged segment and to evaluate the parental chromosomes to rule out the possibility of a cryptic inversion. Precise characterization of any structural chromosome abnormality is important because the nature of it may affect a clinical manifestation in the carrier due to possible gene disruption, creation of a chimeric transcript and/or position effect. It also may shed light on the mechanism of the rearrangement as well as to aid genetic counseling and possible recurrence risk evaluation. Our proband's parental karyotypes were apparently normal based on both GTG and FISH analysis. Therefore, the rearrangement in our patient is considered a de novo event, and given that there is no evidence for the presence of low-copy repeats known to lead to recurrent structural rearrangements by nonallelic homologous recombination, there is no increase in recurrence risk for this couple [Lupski and Stankiewicz, 2005]. Nonhomologous end joining mechanism has been considered as a mechanism for $9 \mathrm{p}$ dup/del as previously described [Chabchoub et al., 2007]. It was postulated that this rearrangement was facilitated by homologous LINE sequences identified at breakpoints on the short arms of chromosome 9 and chromosome 5 with a subsequent end healing by neo-telomere formation and chromosome 5 telomere capture on the der(9) chromosomes. Based on our aCGH and FISH results there is no evidence of exchange of material between the abnormal chromosome 9 and any other chromosome in our patient. 9p rearrangements with scattered breakpoints have been described previously [Christ et al., 1999; Jehee et al., 2005], and rearrangements involving inverted dup/del have been reported for other chromosomes. Several mechanisms leading to such rearrangements were hypothesized, however the causes still remain unclear [Bonaglia et al., 2000; Krepischi-Santos and Vianna-Morgante, 2003]. Elucidation of the mechanism involved in our patient's rearrangement would require extensive molecular workup which is beyond the scope of this report.

Based on the UCSC database there are 45 genes annotated to the deleted and duplicated regions in our patient (online suppl. table 1). From the deleted region, the $D M R T 1,2$, and 3 genes are known to be critical for sexual determination and development. There is evidence for 
Table 3. Clinical features and chromosome breakpoints in patients with pure de novo 9p deletion and duplication

\begin{tabular}{lll}
\hline Authors & Deletion and duplication & Congenital anomalies \\
\hline Our Patient & $\begin{array}{l}\text { del p24.2-pter } \\
\text { dup p21.3-p24 } \\
\text { Inverted }\end{array}$ & $\begin{array}{l}\text { Cleft palate, absent uvula, difficulty with feeding, poor weight gain, clinodactyly, dys- } \\
\text { trophic nails, growth retardation, developmental delay, large palpebral fissures, hyper- } \\
\text { telorism, bulbous nose, cup-shaped ears, mild micrognathia and hypotonia }\end{array}$ \\
\hline $\begin{array}{l}\text { Swinkels et al. } \\
(2008)\end{array}$ & $\begin{array}{l}\text { del p22.2-pter } \\
\text { dup p13.3-p22.2 } \\
\text { Inverted } \\
\text { and } \\
\text { del p22.3-pter } \\
\text { dup p12-p22.3 } \\
\text { Inverted }\end{array}$ & $\begin{array}{l}\text { Developmental delay, trigonocephaly, midface hypoplasia, low-set and posteriorly ro- } \\
\text { tated ears, micro-/retrognathia, tapering fingers, cardiac murmur/deficit, omphalo- } \\
\text { cele }\end{array}$ \\
& $\begin{array}{l}\text { del p22-pter } \\
\text { dup p13-p22 } \\
\text { Inverted }\end{array}$ & $\begin{array}{l}\text { Developmental delay, microcephaly, narrow forehead with metopic ridging, midface } \\
\text { hypoplasia, long tapering fingers, clinodactyly, hypotonia, small nose }\end{array}$ \\
$\begin{array}{l}\text { Teebi et al. } \\
(1993)\end{array}$ & \\
\hline \multicolumn{2}{c}{ Bolding represents features in common with our patient. }
\end{tabular}

haploinsufficiency of these genes, as a result of distal 9p monosomy, resulting in a dosage-dependent mechanism for abnormal testicular and ovarian development in otherwise karyotypically normal males and females [Muroya et al., 2000; Shan et al., 2000; Livadas et al., 2003]. Although at least two 46,XX,del(9p) females reportedly had normal pubertal development [Ounap et al., 2004], close monitoring for impaired pubertal development and ovarian dysfunction is reasonable. Disruption of the DOCK8 gene was reported in 2 unrelated patients with mental retardation and developmental disabilities [Griggs et al., 2008]. Loss of ANKRD15 gene resulting from a common $225-\mathrm{kb}$ deletion at 9 p24.3 was identified in 9 children with congenital cerebral palsy. Based on evidence that ANKRD15 is maternally imprinted, deletion of the paternal copy could have clinical implications [Lerer et al., 2005]. We do not know the relevance of this gene to our patient as the parental origin of her abnormal chromosome 9 is unknown.

Although we are not able to define any specific contribution of the duplicated genes to the phenotype of our patient or to predict potential future complications, it is plausible to assume that altered copy number of genes mapped to the duplicated region (e.g. JAK2 gene) whose role is well documented in many signaling/regulation pathways (i.e. fat metabolism, body growth) may affect the phenotype and contribute to future complications in our patient [Kaushansky, 2005].

To our knowledge, de novo duplication/deletion of $9 \mathrm{p}$ has been precisely characterized by employing routine cytogenetics, FISH, BAC aCGH [Swinkels et al., 2008] and oligonucleotide aCGH (our case) in only 3 patients. It is quite conceivable that some of the previously reported patients with rearrangements of $9 p$ have more complex aberrations with concomitant deletions and duplications undetected by conventional chromosome banding and FISH. Fully characterizing these complex rearrangements may provide clues to the clinical manifestations of the genes in the affected region, as in our patient, the genes in the region of duplication/deletion have not been associated with cleft palate. Such studies with full molecular characterization of cytogenetic findings in patients with duplication/deletions are important to better understand phenotype-karyotype correlations and to define critical regions for identification of candidate genes.

\section{Acknowledgements}

The authors would like to thank Dr. Charles Lee at Brigham and Women's Hospital, Harvard Medical School for his assistance and advice on the array CGH aspects of our patient's evaluation. In addition, we thank our patient's parents who willingly provided the necessary information and samples for this report. We are grateful for their contribution and allowing us to participate in their daughter's care. 


\section{References}

-Alfi O, Donnell GN, Crandall BF, Derencsenyi A, Menon R: Deletion of the short arm of chromosome no.9 (46,9p-): a new deletion syndrome. Ann Genet 16:17-22 (1973).

-Alfi OS, Donnell GN, Allderdice PW, Derencsenyi A: The 9p- syndrome. Ann Genet 19:1116 (1976).

Baccichetti C, Tenconi R: A new case of trisomy for the short arm of No. 9 chromosome. J Med Genet 10:296-299 (1973).

Baccichetti C, Lenzini E, Temperani P, Pallotta R, Giorgi PL, et al: Partial trisomy 9: clinical and cytogenetic correlations. Ann Genet 22: 199-204 (1979).

-Bonaglia MC, Giorda R, Poggi G, Raggi ME, Rossi E, et al: Inverted duplications are recurrent rearrangements always associated with a distal deletion: description of a new case involving 2q. Eur J Hum Genet 8:597603 (2000).

-Bonaglia MC, Giorda R, Carrozzo R, Roncoroni ME, Grasso R, et al: 20-Mb duplication of chromosome $9 \mathrm{p}$ in a girl with minimal physical findings and normal IQ: narrowing of the $9 \mathrm{p}$ duplication critical region to $6 \mathrm{Mb}$. Am J Med Genet 112:154-159 (2002).

-Bussani MC, Giovannucci Uzielli ML, Guarducci S, Nathan G: Four cases of trisomy 9p syndrome with particular chromosome rearrangements. Ann Genet 34:115-119 (1991).

Centerwall WR, Beatty-DeSana JW: The trisomy 9p syndrome. Pediatrics 56:748-755 (1975).

Chabchoub E, Rodriguez L, Galan E, Mansilla E, Martinez-Fernandez ML, et al: Molecular characterisation of a mosaicism with a complex chromosome rearrangement: evidence for coincident chromosome healing by telomere capture and neotelomere formation. J Med Genet 44:250-256 (2007).

Chiyo H, Furuyama J, Suehara N, Obashi Y, Kikkawa H: Possible intrachromosomal duplication in a case of trisomy 9p. Hum Genet 34: 217-221 (1976).

Christ LA, Crowe CA, Micale MA, Conroy JM, Schwartz S: Chromosome breakage hotspots and delineation of the critical region for the 9p-deletion syndrome. Am J Hum Genet 65: 1387-1395 (1999).

Fryns JP, Casaer P, van den Berghe H: Partial duplication of the short arm of chromosome 9 (p13 leads to p22) in a child with typical 9p trisomy phenotype. Hum Genet 46:231-235 (1979).

Fujimoto A, Lin MS, Schwartz S: Direct duplication of 9 p $22 \rightarrow$ p 24 in a child with duplication 9p syndrome. Am J Med Genet 77:268-271 (1998).
Griggs BL, Ladd S, Saul RA, DuPont BR, Srivastava AK: Dedicator of cytokinesis 8 is disrupted in two patients with mental retardation and developmental disabilities. Genomics 91:195-202 (2008).

Guanciali FP, Calabrese G, Morizio E, Modestini E, Stuppia L, et al: FISH analysis in detecting 9p duplication (p22p24). Am J Med Genet 90: 35-37 (2000)

- Haddad BR, Lin AE, Wyandt H, Milunsky A: Molecular cytogenetic characterisation of the first familial case of partial 9p duplication (p22p24). J Med Genet 33:1045-1047 (1996).

Huret JL, Leonard C, Forestier B, Rethore MO, Lejeune J: Eleven new cases of $\operatorname{del}(9 \mathrm{p})$ and features from 80 cases. J Med Genet 25:741749 (1988).

- Iafrate AJ, Feuk L, Rivera MN, Listewnik ML, Donahoe PK, et al: Detection of large-scale variation in the human genome. Nat Genet 36:949-951 (2004).

Jehee FS, Johnson D, Alonso LG, Cavalcanti DP, de Sa ME, et al: Molecular screening for microdeletions at 9p22-p24 and 11q23-q24 in a large cohort of patients with trigonocephaly. Clin Genet 67:503-510 (2005).

Kaushansky K: On the molecular origins of the chronic myeloproliferative disorders: it all makes sense. Blood 105:4187-4190 (2005).

- Kawara H, Yamamoto T, Harada N, Yoshiura K, Niikawa $\mathrm{N}$, et al: Narrowing candidate region for monosomy $9 \mathrm{p}$ syndrome to a $4.7-\mathrm{Mb}$ segment at 9p22.2-p23. Am J Med Genet A 140:373-377 (2006).

Krepischi-Santos AC, Vianna-Morgante AM: Disclosing the mechanisms of origin of de novo short-arm duplications of chromosome 9. Am J Med Genet A 117A:41-46 (2003)

Lerer I, Sagi M, Meiner V, Cohen T, Zlotogora J, Abeliovich D: Deletion of the ANKRD15 gene at 9p24.3 causes parent-of-origin-dependent inheritance of familial cerebral palsy. Hum Mol Genet 14:3911-3920 (2005).

Livadas S, Mavrou A, Sofocleous C, van VlietConstantinidou C, Dracopoulou M, DacouVoutetakis C: Gonadoblastoma in a patient with del(9)(p22) and sex reversal: report of a case and review of the literature. Cancer Genet Cytogenet 143:174-177 (2003).

Lupski JR, Stankiewicz P: Genomic disorders: molecular mechanisms for rearrangements and conveyed phenotypes. PLoS Genet 1:e49 (2005).

Mattina T, Sorge G, Milone G, Garozzo R, Conti L: Duplication 9p due to unequal sister chromatid exchange. J Med Genet 24:303-305 (1987).

Motegi T, Watanabe K, Nakamura N, Hasegawa T, Yanagawa Y: De novo tandem duplication 9p (p12-p24) with normal GALT activity in red cells. J Med Genet 22:64-66 (1985).
Muroya K, Okuyama T, Goishi K, Ogiso Y, Fukuda S, et al: Sex-determining gene(s) on distal 9p: clinical and molecular studies in six cases. J Clin Endocrinol Metab 85:30943100 (2000).

Ogata T, Muroya K, Matsuo N, Hata J, Fukushima Y, Suzuki Y: Impaired male sex development in an infant with molecularly defined partial 9p monosomy: implication for a testis forming gene(s) on 9p. J Med Genet 34:331334 (1997).

Ounap K, Uibo O, Zordania R, Kiho L, Ilus T, et al: Three patients with $9 \mathrm{p}$ deletions including DMRT1 and DMRT2: a girl with XY complement, bilateral ovotestes, and extreme growth retardation, and two XX females with normal pubertal development. Am J Med Genet A 130A:415-423 (2004).

- Rethore MO, Larget-Piet L, Abonyi D, Boeswillwald M, Berger R, et al: [4 cases of trisomy for the short arm of chromosome 9. Individualization of a new morbid entity]. Ann Genet 13:217-232 (1970).

Sanlaville D, Baumann C, Lapierre JM, Romana $\mathrm{S}$, Collot N, et al: De novo inverted duplication 9p21pter involving telomeric repeated sequences. Am J Med Genet 83:125-131 (1999).

Shan Z, Zabel B, Trautmann U, Hillig U, Ottolenghi $\mathrm{C}$, et al: FISH mapping of the sex-reversal region on human chromosome $9 \mathrm{p}$ in two XY females and in primates. Eur J Hum Genet 8:167-173 (2000).

Swinkels ME, Simons A, Smeets DF, Vissers LE, Veltman JA, et al: Clinical and cytogenetic characterization of 13 Dutch patients with deletion 9p syndrome: delineation of the critical region for a consensus phenotype. Am J Med Genet A 146A:1430-1438 (2008).

Teebi AS, Gibson L, McGrath J, Meyn MS, Breg WR, Yang-Feng TL: Molecular and cytogenetic characterization of 9p-abnormalities. Am J Med Genet 46:288-292 (1993).

Temtamy SA, Kamel AK, Ismail S, Helmy NA, Aglan MS, et al: Phenotypic and cytogenetic spectrum of 9 p trisomy. Genet Couns 18:2948 (2007).

Tsezou A, Kitsiou S, Galla A, Petersen MB Karadima G, et al: Molecular cytogenetic characterization and origin of two de novo duplication 9p cases. Am J Med Genet 91: 102-106 (2000).

Wajntal A, Gonzalez CH, Koiffmann CP, de Souza DH: Brief cytogenetic report on maternal translocation $\mathrm{t}(7 ; 9)$ (p22:p13): two sibs with duplication $9 \mathrm{p}$ and one sib with the balanced translocation. Am J Med Genet 20:265-269 (1985). 